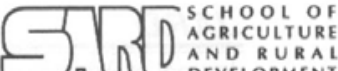
AND RURA I কৃষि ও পঞ্লী উक्্য়ন অনুষদ
Available online at http:/ / www.banglajol.info/index.php/jard
$\mathrm{J}$ ARD

Journal of Agriculture \& Rural Development

\title{
Variability of Different Growth Contributing Parameters of Some Okra (Abelmoschus Esculentus L.) Accessions and Their Interrelation Effects on Yield
}

\author{
A. K. M. A. ALAM $^{1 *}$ \& M. M. Hossain ${ }^{2}$ \\ ${ }^{1}$ School of Agriculture and Rural Development, Bangladesh Open University, Gazipur-1705, Bangladesh \\ ${ }^{2}$ Bangladesh Agricultural University, Mymensingh-2202, Bangladesh
}

\begin{abstract}
The objectives of the study were to assess the variability of growth contributing characters of 50 okra (Abelmoschus esculentus L.) accessions and their interrelation effects on the yield of green pods. The experiment was undertaken at the Horticulture Farm of Bangladesh Agricultural University, Mymensingh during the period from February to May, 2002. There was a wide range of variation for spread of plant $(43.73 \mathrm{~cm})$, height of plant $(80.90 \mathrm{~cm})$ and length of petiole $(12.31 \mathrm{~cm})$. Moderate variation for number of nodes per plant (14.58), number of leaves per plant (24.51 at 80 DAS), length of leaf $(12.20 \mathrm{~cm})$, breadth of leaf $(13.05 \mathrm{~cm})$; and lesser variation for number of primary branches per plant (1.57) was observed. The yield of green pod varied significantly and ranged from 4.39 t/ha (accession 19) to 12.77 t/ha (accession 69) with the average value of 7.86 t/ha. Number of primary branches per plant, which showed a lesser range of variation, recorded the highest genotypic coefficient of variation (GCV= 26.56\%) and also the highest phenotypic co-efficient of variation (PCV = $32.37 \%)$. A moderate GCV and PCV were recorded in case of length of petiole (GCV $=14.24 \%$ and $P C V=15.95 \%)$, spread of plant $(G C V=12.00 \%$ and $P C V=13.06 \%)$, breadth of leaf $(G C V=9.81 \%$ and $P C V=12.41 \%)$ and length of leaf $(G C V=9.53 \%$ and $P C V=13.35 \%)$. These characters suggested the existence of justifiable genetic and phenotypic distance among different accessions. Correlation co-efficient between yield and growth contributing parameters indicated that yield of green pod had highly significant positive association with the number of nodes per plant. Path analysis of different growth contributing parameters showed that number of nodes per plant directly contributed towards the yield of green pod.
\end{abstract}

Key words: Okra accessions, variability, growth parameters, GCV, PCV, path analysis.

\section{INTRODUCTION}

Abelmoschus esculentus (L.) Moench, commonly called okra or lady's finger, is believed to be native to tropical Africa. It is an important vegetable crop throughout the tropics and subtropics (Hammon and Van Sloten, 1989) and also well distributed in the Indian subcontinent and East Asia (Kochhar, 1986). The vegetable okra is an important source of protein, minerals, vitamins and roughage for those populations that include it as part of their diet (Rashid, 1999).

In Bangladesh perspective, the annual vegetable production is not uniformly distributed among the seasons. Since okra is photo insensitive, it has got great importance to produce in the lean

* Corresponding author: Assistant Professor (Horticulture), SARD, BOU, Gazipur-1705, E-mail: akmaalam@yahoo.com

(C) 2008 School of Agriculture and Rural Development, Bangladesh Open University, All rights reserved. 
summer season (Anon., 1993). However, the acreage and production of okra was being increased gradually from 5929 ha and 18205 ton in 1999-2000 to 7152 ha and 24230 ton in 2003-2004, respectively (BBS, 2004). But the yield of okra is very low compared to that of other developing countries. The yield of okra in Bangladesh is low particularly due to lack of high yielding varieties. For improving the production as well as yield of okra in the country, the "Conservation of Vegetable and Fruits in Bangladesh (CVFB)" project, has collected some okra accessions from different parts of Bangladesh and are being evaluated at the Department of Horticulture, Bangladesh Agricultural University, Mymensingh.

Progress in crop production depends largely on the ability of the breeders to select high yielding varieties. Considerable effort is currently being made in a number of okra breeding program to improve yield attributes such as seed yield, number of pods per plant, pod length and pod width. These traits are particularly important in the breeding program of okra. The vegetative traits are also an important measure of yield and should be considered; number of pods per plant, days to flowering and plant height are some of the most variable quantitative characters of okra (Singh and Singh, 1977). Variation is a necessary condition for selection programme aimed at improving some desirable traits. The basic key to bring about the genetic upgrading to a plant is to utilize the available or created genetic variability. If the variability in the population is largely due to genetic cause with least environmental effect, the probability of a superior genotype is much higher for the expression of desired characters.

With the view of above facts, the present study was undertaken to determine the performance and variability of okra accessions for yield and to assess the interrelationships between yield and growth contributing characters.

\section{MATERIALS AND METHODS}

The experiment was conducted at the Horticulture Farm, Bangladesh Agricultural University, Mymensingh during the period from February to May, 2002. The average maximum temperature during the period of experiment was $31.82^{\circ} \mathrm{C}$ and the average minimum temperature was $24.14^{\circ} \mathrm{C}$. The soil texture was silty loam with $\mathrm{pH}$ value of 6.7. Fifty okra accessions were used in this study which was collected by the Conservation of Vegetables and Fruits in Bangladesh (CVFB) project from different parts of the country. These 50 accessions were considered as the treatments of the experiment and chosen primarily to represent the commercial types of okra grown in different parts of Bangladesh like Jamalpur (5), Mymensingh (7), Tangail (3), Pabna (7), Rajshahi (2), Natore (3), Gaibandha (1), Dinajpur (1), Panchaghar (1), Comilla (9), Chittagong (9) and Rangunia (2). The sources of the 50 okra accessions are summarized in Table 1 . The experiment was laid out in the Randomized Complete Block Design (RCBD) with three replications. One accession represented one treatment and seven plants in an accession represented one replication. The distance between replication to replication was $1 \mathrm{~m}$, plant to plant $45 \mathrm{~cm}$ and row to row $50 \mathrm{~cm}$. The experimental plots were properly prepared and added recommended doses of manures and fertilizers (Anon., 1998). Other intercultural operations were done as and when necessary. Then green pods were harvested regularly when they attained edible stage. Harvesting started from 18 April 2002 and continued up to the last period.

Data on the 5 selected growth contributing characters such as height of plant, number of primary branches per plant, spread of plant, number of nodes per plant and number of leaves per plant at 80 DAS (Days After Sowing) were recorded from the sample plants during the experiment. Data on the 5 selected leaf characteristics in respect of length, breadth, petiole length, shape and colour were also recorded time to time during the experiment. Finally, the yield of green pods was calculated properly. The data were analyzed using MSTAT-C and GENSTAT software to find out the significance of difference among the treatment means phenotypic co-efficient of variation (PCV) and genotypic co-efficient of variation (GCV). The significance of the difference between treatments means was evaluated by least significance difference (LSD) test for the interpretation of the results (Gomez and Gomez, 1984). Simple correlation co-efficient (r) among five important growth contributing characters of okra accessions was estimated regarding the formula followed by Singh and Chaudhury (1985). Path co-efficient analysis was done according to the procedure employed by Dewey and Lu (1959) using simple correlation values. 
Table 1. Accession number and sources of 50 okra accessions

\begin{tabular}{|c|c|c|c|c|c|}
\hline Treatment & Accession No. & Source & Treatment & Accession No. & Source \\
\hline $\mathrm{T}_{1}$ & 3 & Jamalpur & $\mathrm{T}_{26}$ & 48 & Gaibandha \\
\hline $\mathrm{T}_{2}$ & 5 & Jamalpur & $\mathrm{T}_{27}$ & 50 & Comilla \\
\hline $\mathrm{T}_{3}$ & 7 & Jamalpur & $\mathrm{T}_{28}$ & 52 & Comilla \\
\hline $\mathrm{T}_{4}$ & 8 & Jamalpur & $\mathrm{T}_{29}$ & 53 & Comilla \\
\hline $\mathrm{T}_{5}$ & 9 & Jamalpur & $\mathrm{T}_{30}$ & 54 & Comilla \\
\hline $\mathrm{T}_{6}$ & 11 & Mymensingh & $\mathrm{T}_{31}$ & 55 & Comilla \\
\hline $\mathrm{T}_{7}$ & 12 & Mymensingh & $\mathrm{T}_{32}$ & 56 & Comilla \\
\hline $\mathrm{T}_{8}$ & 13 & Mymensingh & $\mathrm{T}_{33}$ & 57 & Comilla \\
\hline $\mathrm{T}_{9}$ & 14 & Pabna & $\mathrm{T}_{34}$ & 58 & Comilla \\
\hline $\mathrm{T}_{10}$ & 18 & Mymensingh & $\mathrm{T}_{35}$ & 59 & Comilla \\
\hline $\mathrm{T}_{11}$ & 19 & Mymensingh & $\mathrm{T}_{36}$ & 60 & Chittagong \\
\hline $\mathrm{T}_{12}$ & 21 & Panchagarh & $\mathrm{T}_{37}$ & 61 & Chittagong \\
\hline $\mathrm{T}_{13}$ & 25 & Tangail & $\mathrm{T}_{38}$ & 62 & Chittagong \\
\hline $\mathrm{T}_{14}$ & 28 & Tangail & $\mathrm{T}_{39}$ & 63 & Chittagong \\
\hline $\mathrm{T}_{15}$ & 29 & Tangail & $\mathrm{T}_{40}$ & 64 & Chittagong \\
\hline $\mathrm{T}_{16}$ & 30 & Mymensingh & $\mathrm{T}_{41}$ & 65 & Chittagong \\
\hline $\mathrm{T}_{17}$ & 31 & Pabna & $\mathrm{T}_{42}$ & 66 & Rangunia \\
\hline $\mathrm{T}_{18}$ & 32 & Pabna & $\mathrm{T}_{43}$ & 67 & Rangunia \\
\hline $\mathrm{T}_{19}$ & 34 & Pabna & $\mathrm{T}_{44}$ & 69 & Chittagong \\
\hline $\mathrm{T}_{20}$ & 35 & Pabna & $\mathrm{T}_{45}$ & 70 & Chittagong \\
\hline $\mathrm{T}_{21}$ & 36 & Pabna & $\mathrm{T}_{46}$ & 71 & Chittagong \\
\hline $\mathrm{T}_{22}$ & 38 & Pabna & $\mathrm{T}_{47}$ & 72 & Natore \\
\hline $\mathrm{T}_{23}$ & 39 & Mymensingh & $\mathrm{T}_{48}$ & 74 & Natore \\
\hline $\mathrm{T}_{24}$ & 43 & Rajshahi & $\mathrm{T}_{49}$ & 75 & Natore \\
\hline $\mathrm{T}_{25}$ & 44 & Rajshahi & $\mathrm{T}_{50}$ & 77 & Dinajpur \\
\hline
\end{tabular}

\section{RESULTS AND DISCUSSION}

The variability of different growth contributing parameters such as plant characteristics like height of plant, number of primary branches per plant, spread of plant, number of nodes per plant, number of leaves per plant; and leaf characteristics like length of leaf, breadth of leaf, length of petiole, shape of leaf and color of leaf towards yield of the 50 okra accessions were recorded as well as observed. Their correlation co-efficient, genotypic and phenotypic variations, direct and indirect effects of traits through path analysis as regards on yield of green pod were estimated and shown in different tables, figures and plates.

\section{Plant characteristics}

Data based on plant characteristics like height of plant, number of primary branches per plant, spread of plant, number of nodes per plant and number of leaves per plant were recorded and shown in Table 2, Fig. 1 and Table 4.

\section{Height of plant}

The height of plant as observed in this experiment varied significantly among the accessions. The tallest plant at 80 DAS was found in accession number $69(92.53 \mathrm{~cm})$ which was followed by accession number $65(89.88 \mathrm{~cm})$. On the other hand the shortest plant at 80 DAS was recorded in accession number $19(70.20 \mathrm{~cm})$ which was statistically similar with the accession number 9,21 , 28, and 77 (Table 2).

The environmental influence was considerable for this trait which could be observed from the differences between genotypic variance (24.93) and phenotypic variance (29.97) and also the differences between genotypic co-efficient of variation (6.17\%) and phenotypic co-efficient of variation (6.76\%) at 80 DAS as shown in Table 4 . The trait was highly potential for selection. 
Table 2. Plant characteristics in respect to plant height, number of primary branches, number of nodes and number of leaves per plant of 50 okra accessions

\begin{tabular}{|c|c|c|c|c|}
\hline Treatments & Plant height $(\mathrm{cm})$ & $\begin{array}{l}\text { No. of primary } \\
\text { branches/plant }\end{array}$ & No. of nodes/plant & No. of leaves/plant \\
\hline T1(A3) & 80.95 & 1.63 & 14.69 & 24.94 \\
\hline T2(A5) & 74.33 & 1.33 & 15.42 & 23.53 \\
\hline T3A7) & 80.51 & 2.76 & 15.89 & 25.55 \\
\hline T4(A8) & 76.22 & 1.42 & 15.70 & 25.36 \\
\hline T5(A9) & 72.16 & 1.07 & 13.46 & 21.46 \\
\hline T6(A11) & 77.20 & 1.36 & 15.05 & 24.99 \\
\hline T7(A12) & 83.61 & 1.61 & 15.35 & 25.92 \\
\hline T8(A13) & 81.56 & 1.35 & 14.38 & 24.71 \\
\hline T9(A14) & 81.06 & 1.86 & 14.62 & 24.10 \\
\hline T10(A18) & 77.79 & 1.49 & 13.49 & 23.93 \\
\hline T11(A19) & 70.20 & 3.00 & 11.44 & 27.35 \\
\hline T12(A21) & 73.78 & 1.11 & 14.66 & 25.22 \\
\hline $\mathrm{T} 13(\mathrm{~A} 25)$ & 67.24 & 1.10 & 14.73 & 22.33 \\
\hline T14(A28) & 74.00 & 1.40 & 13.27 & 24.45 \\
\hline T15(A29) & 79.63 & 1.50 & 14.43 & 23.07 \\
\hline T16(А30) & 78.46 & 1.47 & 14.07 & 21.66 \\
\hline T17(A31) & 82.33 & 1.78 & 13.90 & 23.80 \\
\hline T18(A32) & 79.24 & 1.40 & 16.58 & 24.00 \\
\hline T19(A34) & 76.20 & 1.20 & 14.47 & 25.03 \\
\hline T20(A35) & 78.64 & 1.50 & 14.27 & 21.66 \\
\hline T21(A36) & 83.20 & 2.00 & 15.27 & 25.27 \\
\hline T22(A38) & 76.45 & 2.67 & 14.53 & 25.81 \\
\hline T23(А39) & 80.86 & 1.80 & 14.85 & 25.53 \\
\hline T24(A43) & 81.78 & 1.40 & 14.10 & 24.33 \\
\hline T25(A44) & 85.55 & 2.07 & 14.94 & 22.83 \\
\hline T26(A48) & 78.35 & 1.35 & 15.84 & 24.33 \\
\hline T27(A50) & 81.33 & 1.32 & 14.06 & 24.00 \\
\hline T28(A52) & 83.00 & 1.07 & 11.76 & 24.07 \\
\hline T29(A53) & 85.56 & 1.31 & 14.07 & 23.69 \\
\hline T30(A54) & 78.11 & 1.93 & 15.92 & 24.96 \\
\hline T31(A55) & 86.63 & 1.53 & 13.43 & 23.48 \\
\hline T32(A56) & 84.32 & 1.22 & 14.13 & 24.04 \\
\hline T33(A57) & 81.33 & 1.13 & 15.72 & 24.13 \\
\hline T34(A58) & 85.33 & 1.80 & 14.00 & 26.08 \\
\hline T35(A59) & 82.04 & 1.16 & 14.28 & 23.47 \\
\hline T36(A60) & 79.43 & 1.24 & 14.95 & 25.20 \\
\hline T37(A61) & 81.96 & 1.49 & 13.08 & 26.10 \\
\hline T38(A62) & 88.43 & 1.55 & 17.30 & 26.37 \\
\hline T39(A63) & 87.44 & 1.82 & 13.51 & 22.90 \\
\hline T40(A64) & 82.60 & 1.33 & 13.69 & 24.04 \\
\hline T41(A65) & 89.88 & 1.00 & 17.53 & 26.40 \\
\hline T42(A66) & 85.98 & 2.67 & 14.38 & 27.10 \\
\hline T43(A67) & 85.77 & 2.17 & 14.26 & 26.62 \\
\hline T44(A69) & 92.53 & 1.00 & 18.16 & 26.46 \\
\hline T45(A70) & 85.43 & 1.49 & 14.11 & 26.10 \\
\hline T46(A71) & 76.22 & 1.33 & 13.35 & 25.77 \\
\hline T47(A72) & 87.00 & 1.82 & 13.90 & 23.33 \\
\hline T48(A74) & 87.00 & 1.46 & 15.44 & 24.48 \\
\hline T49(A75) & 82.38 & 1.78 & 14.13 & 22.70 \\
\hline T50(A77) & 73.99 & 1.19 & 14.36 & 22.93 \\
\hline Range & $70.20-92.53$ & $1.00-3.00$ & $11.44-18.16$ & $21.46-27.35$ \\
\hline Mean value & 80.90 & 1.58 & 14.58 & 24.51 \\
\hline $\operatorname{LSD}(0.05)$ & 3.64 & 0.47 & 1.90 & 1.30 \\
\hline
\end{tabular}




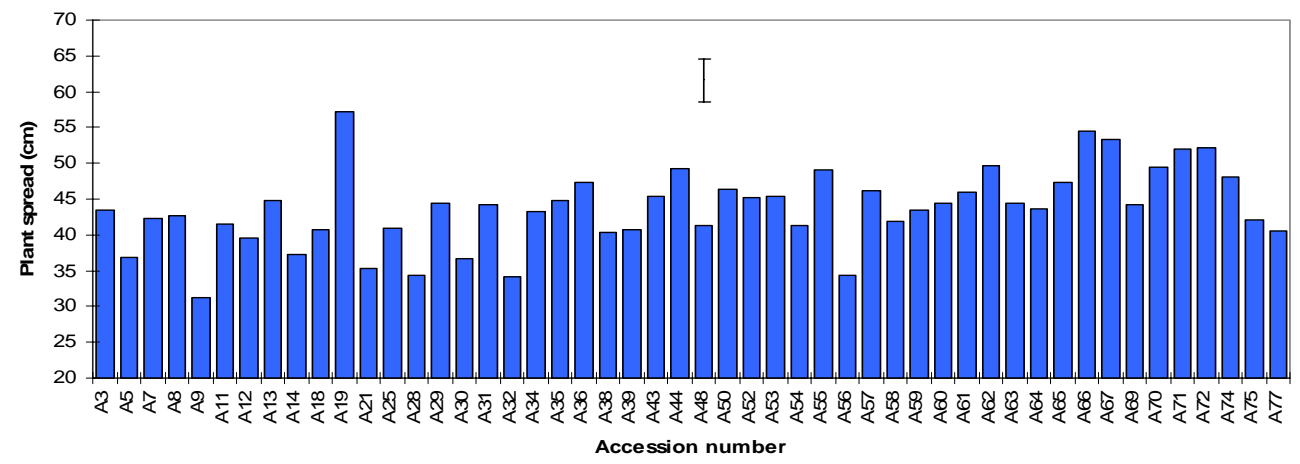

Fig. 1. Plant spread of 50 okra accessions. Vertical bar represents LSD at $5 \%$ level of probability.

\section{Number of primary branches per plant}

Significant variation in respect of number of primary branches per plant among the accessions was found. The number of primary branches per plant ranged from 1.00 to 3.00 with the mean value of 1.58. The accession number 19 had the highest number of primary branches per plant (3.00) followed by accession number 38, 66 and 67 (2.67, 2.67 and 2.17, respectively) while accession number 9 and 69 had the least similar number of primary branches (1.00) per plant which was statistically similar with the accession number $5,8,9,13,21,25,28,30,32,34,43,48,50,52,53,56,57,59,64,71,74$ and 77 (Table 2). This is in conformity with the finding of Dash and Mishra (1995) who observed significant differences in number of primary branches per plant among 27 okra cultivars.

Little differences were observed between phenotypic (0.258) and genotypic (0.174) variance as well as phenotypic (32.37\%) and genotypic (26.56\%) co-efficient of variation indicating low environmental influence on this trait (Table 4). This result is also supported by Das and Mishra (1995) who observed phenotypic and genotypic co-efficient of variation on primary branches per plant in okra.

\section{Spread of plant}

Spread of plants as observed in this study varied significantly and ranged from $31.24 \mathrm{~cm}$ to 57.15 $\mathrm{cm}$ with the mean value of $43.73 \mathrm{~cm}$ as shown in Table 4. The highest spread of plant $57.15 \mathrm{~cm}$ was found in accession number 19 followed by accession number $66,67(54.44,53.42 \mathrm{~cm}$, respectively) whereas, the lowest spread of plant $(31.24 \mathrm{~cm})$ was observed in accession number 9 which was statistically similar with the accession number 28, 32 and 56 (Fig. 1). This result agreed with the findings of Gondane and Bahatia (1995) and Martin and Rhodes (1983) who observed considerable variation of spread of plant in okra.

Considerable differences between phenotypic $(32.65 \mathrm{~cm})$ and genotypic $(27.54 \mathrm{~cm})$ variances as well as phenotypic (13.06\%) and genotypic (12.00\%) co-efficient of variation indicating considerable environmental effect on the expression of the character of plant spread (Table 4). Singh et al. (1998) reported similar result in respect of plant spread.

\section{Number of nodes per plant}

The number of nodes per plant ranged from 11.44 to 18.16 (Table 4). The highest number of nodes was found in of accession number 69 (18.16) which were statistically significant and different from all other accessions. The other accessions such as 65 and 62 also showed higher number of nodes per plant. In contrast, the lowest number of nodes per plant was observed in the accession number 19 (11.44) which was statistically similar with the accession number 9, 18, 28, 52, 55, 61, 63, 64 and 71 (Table 2). This result agrees with that of Gondane and Bahatia (1995) who also reported significant differences among the genotypes for number of nodes per plant.

Considerable differences between phenotypic (2.45) and genotypic (1.09) variances as well as phenotypic (10.75\%) and genotypic (7.16\%) co-efficient of variation (Table 4) indicating considerable environmental effect on the expression of the character of number of nodes per plant. Sood et al. (1995) reported similar result in respect of number of nodes per plant in okra. 


\section{Number of leaves per plant}

Significant variation in respect of number of leaves per plant among the accessions was found. The maximum number of leaves per plant was produced by the accession number 19 (27.35 at 80 DAS). It was followed by the accession number $66(27.10)$ and $67(26.62)$ at 80 DAS. The corresponding minimum number of leaves per plant was recorded in accession number 9 (21.46 at 80 DAS) which was statistically similar with the accession number 25, 30, 35, 44, 63, 75 and 77 (Table 2). These results are in full conformity with Gondane and Bahatia (1995); Martin and Rhodes (1983) who found significant varietal differences for the number of leaves per plant in okra.

Higher genotypic variance compared to phenotypic variance was not found at 80 DAS (Table 4). Genotypic co-efficient of variation was also lower than the corresponding phenotypic one which indicated the larger influence of environment. The result of this study agrees with the findings of Sood et al. (1995).

\section{Leaf characteristics}

The leaf characteristics like length of leaf, breadth of leaf, length of petiole, shape of leaf and color of leaf were recorded and shown in Table 3, Plate 1 and Table 4.

Table 3. Leaf characteristics in respect of length, breadth, petiole length, shape and color of 50 okra accessions

\begin{tabular}{|c|c|c|c|c|c|}
\hline Treatments & Length of leaf (cm) & Breadth of leaf (cm) & Length of petiole $(\mathrm{cm})$ & Shape of leaf & Color of leaf \\
\hline T1(A3) & 7.13 & 11.68 & 13.98 & Palmatipartite & Green \\
\hline T2(A5) & 11.67 & 14.33 & 10.22 & Palmatifid & Deep green \\
\hline T3(A7) & 12.73 & 14.55 & 13.63 & Palmatipartite & Green \\
\hline T4(A8) & 12.13 & 12.95 & 13.31 & Palmatipartite & Green \\
\hline T5(A9) & 10.44 & 14.11 & 8.44 & Palmatisect & Green \\
\hline T6(A11) & 11.33 & 13.12 & 14.55 & Palmatisect & Light green \\
\hline T7(A12) & 10.63 & 12.33 & 15.33 & Palmatisect & Light green \\
\hline T8(A13) & 12.28 & 12.01 & 14.97 & Palmatisect & Green \\
\hline T9(A14) & 12.00 & 14.22 & 14.08 & Palmatipartite & Green \\
\hline T10(A18) & 12.30 & 12.31 & 13.33 & Palmatisect & Green \\
\hline T11(A19) & 10.18 & 11.16 & 11.75 & Palmatipartite & Light green \\
\hline T12(A21) & 10.45 & 11.46 & 13.05 & Palmatipartite & Green \\
\hline T13(A25) & 9.62 & 11.54 & 10.55 & Palmatipartite & Green \\
\hline T14(A28) & 10.99 & 11.27 & 11.36 & Palmatipartite & Green \\
\hline T15(A29) & 11.33 & 12.54 & 14.00 & Palmatisect & Green \\
\hline T16(A30) & 12.00 & 10.77 & 13.64 & Palmatisect & Green \\
\hline T17(A31) & 13.27 & 12.24 & 15.13 & Palmatisect & Green \\
\hline T18(A32) & 12.00 & 13.11 & 11.66 & Palmatifid & Deep green \\
\hline T19(A34) & 13.00 & 11.41 & 15.68 & Palmatipartite & Green \\
\hline T20(A35) & 12.33 & 12.60 & 14.66 & Palmatipartite & Green \\
\hline T21(A36) & 13.51 & 12.61 & 15.27 & Palmatisect & Light green \\
\hline T22(A38) & 11.36 & 13.61 & 13.33 & Palmatipartite & Deep green \\
\hline T23(A39) & 12.00 & 14.06 & 15.00 & Palmatisect & Deep green \\
\hline T24(A43) & 13.38 & 14.16 & 13.16 & Palmatifid & Deep green \\
\hline T25(A44) & 13.64 & 14.23 & 15.22 & Palmatipartite & Green \\
\hline T26(A48) & 12.83 & 14.11 & 13.10 & Palmatisect & Deep green \\
\hline T27(A50) & 11.66 & 12.31 & 15.00 & Palmatisect & Green \\
\hline T28(A52) & 11.77 & 14.24 & 16.33 & Palmatisect & Deep green \\
\hline T29(A53) & 13.00 & 14.56 & 15.41 & Palmatisect & Green \\
\hline T30(A54) & 11.66 & 11.83 & 14.16 & Palmatipartite & Green \\
\hline T31(A55) & 13.11 & 11.42 & 15.26 & Palmatipartite & Green \\
\hline T32(A56) & 13.12 & 14.22 & 14.11 & Palmatisect & Green \\
\hline T33(A57) & 10.66 & 12.42 & 15.55 & Palmatisect & Green \\
\hline T34(A58) & 11.44 & 11.22 & 14.55 & Palmatipartite & Green \\
\hline T35(A59) & 12.27 & 12.83 & 15.16 & Palmatipartite & Light green \\
\hline T36(A60) & 10.55 & 12.34 & 14.20 & Palmatipartite & Light green \\
\hline T37(A61) & 12.83 & 13.77 & 15.50 & Palmatipartite & Green \\
\hline T38(A62) & 12.38 & 14.77 & 16.66 & Palmatipartite & Green \\
\hline T39(A63) & 13.22 & 14.20 & 14.42 & Palmatipartite & Green \\
\hline T40(A64) & 13.22 & 12.15 & 15.02 & Palmatipartite & Green \\
\hline T41(A65) & 14.55 & 15.50 & 17.00 & Palmatipartite & Green \\
\hline T42(A66) & 12.63 & 13.83 & 16.33 & Palmatipartite & Green \\
\hline T43(A67) & 13.20 & 13.13 & 16.23 & Palmatipartite & Green \\
\hline T44(A69) & 15.50 & 17.97 & 19.20 & Palmatipartite & Green \\
\hline T45(A70) & 14.20 & 13.11 & 14.20 & Palmatipartite & Light green \\
\hline T46(A71) & 14.20 & 14.41 & 16.42 & Palmatisect & Light green \\
\hline T47(A72) & 13.24 & 14.29 & 14.16 & Palmatisect & Deep green \\
\hline T48(A74) & 14.00 & 12.34 & 14.13 & Palmatisect & Deep green \\
\hline T49(A75) & 11.76 & 13.66 & 14.76 & Palmatipartite & Deep green \\
\hline T50(A77) & 12.55 & 14.11 & 13.49 & Palmatifid & Deep green \\
\hline Range & $7.13-15.50$ & $10.77-17.97$ & $8.44-19.20$ & - & - \\
\hline Mean value & 12.20 & 13.05 & 12.31 & - & - \\
\hline LSD (0.05) & 1.84 & 1.60 & 1.44 & - & - \\
\hline
\end{tabular}



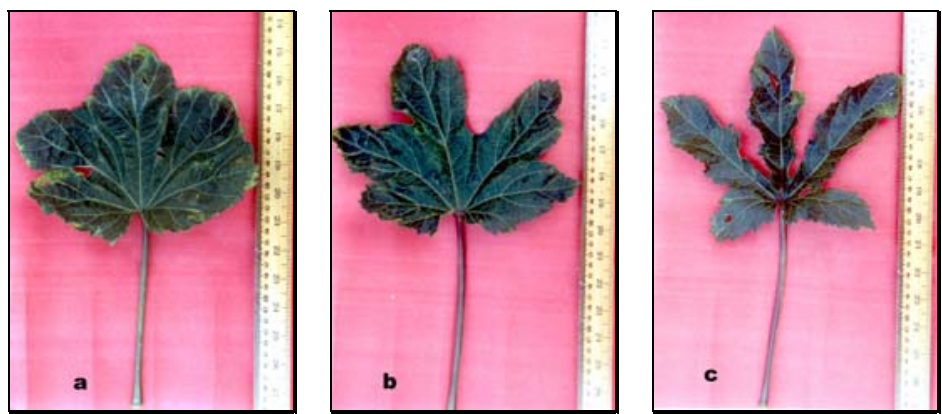

Plate 1. Photograph showing the different shape of leaves among the studied accessions of okra ( $a, b$ and c shows palmatifid, palmatipartite and palmatisect leaves, respectively)

Table 4. Genotypic variance, phenotypic variance, genotypic co-efficient of variation, phenotypic co-efficient of variation, range and mean of growth contributing parameters towards yield of $\mathbf{5 0}$ okra accessions

\begin{tabular}{|c|c|c|c|c|c|c|c|c|c|}
\hline Character & $\begin{array}{l}\text { Plant height } \\
(\mathrm{cm})\end{array}$ & $\begin{array}{c}\text { No. of } \\
\text { primary } \\
\text { branches } \\
\text { per plant }\end{array}$ & $\begin{array}{l}\text { Spread of } \\
\text { plant }(\mathrm{cm})\end{array}$ & $\begin{array}{l}\text { No. of } \\
\text { nodes per } \\
\text { plant }\end{array}$ & $\begin{array}{l}\text { No. of } \\
\text { leaves per } \\
\text { plant }\end{array}$ & $\begin{array}{l}\text { Length of } \\
\text { leaf }(\mathrm{cm})\end{array}$ & $\begin{array}{l}\text { Breadth of } \\
\text { leaf }(\mathrm{cm})\end{array}$ & $\begin{array}{l}\text { Length of } \\
\text { petiole }(\mathrm{cm})\end{array}$ & $\begin{array}{l}\text { Yield of } \\
\text { green pod } \\
\text { (t/ha) }\end{array}$ \\
\hline $\begin{array}{l}\text { Genotypic } \\
\text { variance }\end{array}$ & 24.93 & 0.174 & 27.54 & 1.09 & 1.78 & 1.35 & 1.64 & 3.07 & 3.33 \\
\hline $\begin{array}{l}\text { Phenotypic } \\
\text { variance } \\
\text { Genotypic }\end{array}$ & 29.97 & 0.258 & 32.65 & 2.45 & 2.65 & 2.65 & 2.62 & 3.85 & 4.53 \\
\hline $\begin{array}{l}\text { co-efficient of } \\
\text { variation (\%) }\end{array}$ & 6.17 & 26.56 & 12.00 & 7.16 & 5.40 & 9.53 & 9.81 & 14.24 & 23.22 \\
\hline $\begin{array}{l}\text { Phenotypic } \\
\text { co-efficient of } \\
\text { variation (\%) }\end{array}$ & 6.76 & 32.37 & 13.06 & 10.75 & 6.40 & 13.35 & 12.41 & 15.95 & 27.11 \\
\hline Range & $70.20-92.53$ & $1.00-3.00$ & $31.24-57.15$ & $11.44-18.16$ & $21.46-27.35$ & $7.13-15.50$ & $10.77-17.97$ & $8.44-19.20$ & $4.39-12.77$ \\
\hline Mean \pm SE & $80.90 \pm 0.75$ & $1.58 \pm 0.96$ & $43.73 \pm 0.75$ & $14.58 \pm 0.39$ & $24.51 \pm 0.28$ & $12.20 \pm 0.38$ & $13.05 \pm 0.33$ & $12.31 \pm 0.30$ & $7.86 \pm 0.15$ \\
\hline
\end{tabular}

\section{Length of leaf}

In regards to length of leaf it was observed that it varied significantly and ranged from $7.13 \mathrm{~cm}$ to $15.50 \mathrm{~cm}$ with the mean value of $12.20 \mathrm{~cm}$. The longest length of leaf $(15.50 \mathrm{~cm})$ was found in accession 69 which was followed by accession number 65,70 and $71(14.55,14.20$ and $14.20 \mathrm{~cm}$, respectively). The shortest length of leaf was $(7.13 \mathrm{~cm}$ ) was found in accession 3 (Table 3 ). These results agreed with the findings of Gondane and Bahatia (1995).

Considerable differences between phenotypic $(2.65 \mathrm{~cm})$ and genotypic $(1.35 \mathrm{~cm})$ variances as well as phenotypic (13.35\%) and genotypic (9.53\%) co-efficient of variation indicating considerable environmental effect on the expression of the character of leaf length (Table 4). This result was supported by Lotilo (1989).

\section{Breadth of leaf}

It was revealed that breadth of leaf ranged from $10.77 \mathrm{~cm}$ to $17.97 \mathrm{~cm}$ varied significantly with the mean value of $13.05 \mathrm{~cm}$ among the accessions. The plants of accession number 69 showed the highest breadth of leaf $(17.97 \mathrm{~cm})$ which was followed by accession number $65,62(15.50,14.77$ $\mathrm{cm}$, respectively). The lowest breadth of leaf $(10.77 \mathrm{~cm})$ was observed in accession number 30 which was statistically similar with the accession number 12, 13, 31, 50, 56, 63 and 74 (Table 3). These results agreed with the findings of Martin and Rhodes (1983).

Considerable differences between phenotypic (12.41\%) and genotypic (9.81\%) co-efficient of variation indicating considerable environmental effect on the expression of this character (Table 4). The result of this study agrees with the findings of Lotilo (1989) who reported the phenotypic coefficient of variation (PCV) was higher than the genotypic co-efficient of variation (GCV). 


\section{Length of petiole}

The results on length of petiole of leaves varied significantly and ranged from $8.44 \mathrm{~cm}$ to $19.20 \mathrm{~cm}$ with the mean value of $12.31 \mathrm{~cm}$. The longest length of petiole $(19.20 \mathrm{~cm})$ was found in accession number 69 which was followed by accession number 65 and 62 (17.00 and $16.66 \mathrm{~cm}$, respectively). The lowest length of petiole $(8.44 \mathrm{~cm})$ was observed in accession number 9 (Table 3). Gondane and Bahatia (1995); Hazra and Basu (2000) reported that similar result in respect of length of petiole.

Little differences were observed between phenotypic (3.85) and genotypic (3.07) variance as well as phenotypic (15.95\%) and genotypic (14.24\%) co-efficient of variation indicating low environmental influence on this trait (Table 4). It was supported by Lotilo (1989) who observed GCV and PCV in okra.

\section{Shape of leaf}

From Table 3, it can be seen that the leaves of accession numbers $9,11,12,13,18,29,30,31,36$, $39,48,50,52,53,56,57,71,72$ and 74 were palmatisect and the accession no. 5, 32, 43 and 77 were palmatifid shaped. Rest of the accessions had palmatipartite shaped leaves. The three different shapes of the leaves have been shown in Table 3 and Plate 1. Kuwada (1964) observed similar shape of leaf in okra.

\section{Colour of leaf}

Accessions were grouped into 3 on the basis of their colour of leaf. There are light green, green and deep green. The deep green leaves were found in accession 5, 32, 38, 39, 43, 48, 52, 72, 74, 75 and 77. Light green leaves were observed in accession 11, 12, 19, 36, 59, 60, 70 and 71. Green leaves observed in accession $3,7,8,9,13,14,18,21,25,28,30,31,34,35,44,50,53,54,55$, $57,58,61,62,63,64,65,66$ and 69 (Table 3). Similar result was supported by Kuwada (1964) who observed colour of leaf in 29 okra varieties.

\section{Yield of green pod}

Among the observed accessions, yield of green pod varied significantly and ranged from $4.39 \mathrm{t} / \mathrm{ha}$ to $12.77 \mathrm{t} / \mathrm{ha}$ with the average value of $7.86 \mathrm{t} / \mathrm{ha}$ (Table 4). The maximum yield of green pod (12.77 t/ha) was obtained in the accession 69 followed by accessions 65, 62, 57 and $13(12.32,11.93$, 10.49 and 10.57 t/ha respectively) whereas the minimum yield of green pod (4.39 t/ha) was obtained from accession 19 which was statistically similar with the accession 7, 14, 28, 29, 39, 50, 52, 61 and 64 (5.48, 5.95, 5.23, 5.67, 6.00, 5.60, 5.19, 4.54 and 6.17 t/ha respectively) (Fig. 2). This result agrees with the findings of Hussein et al. (1994); Martin and Rhodes (1983).

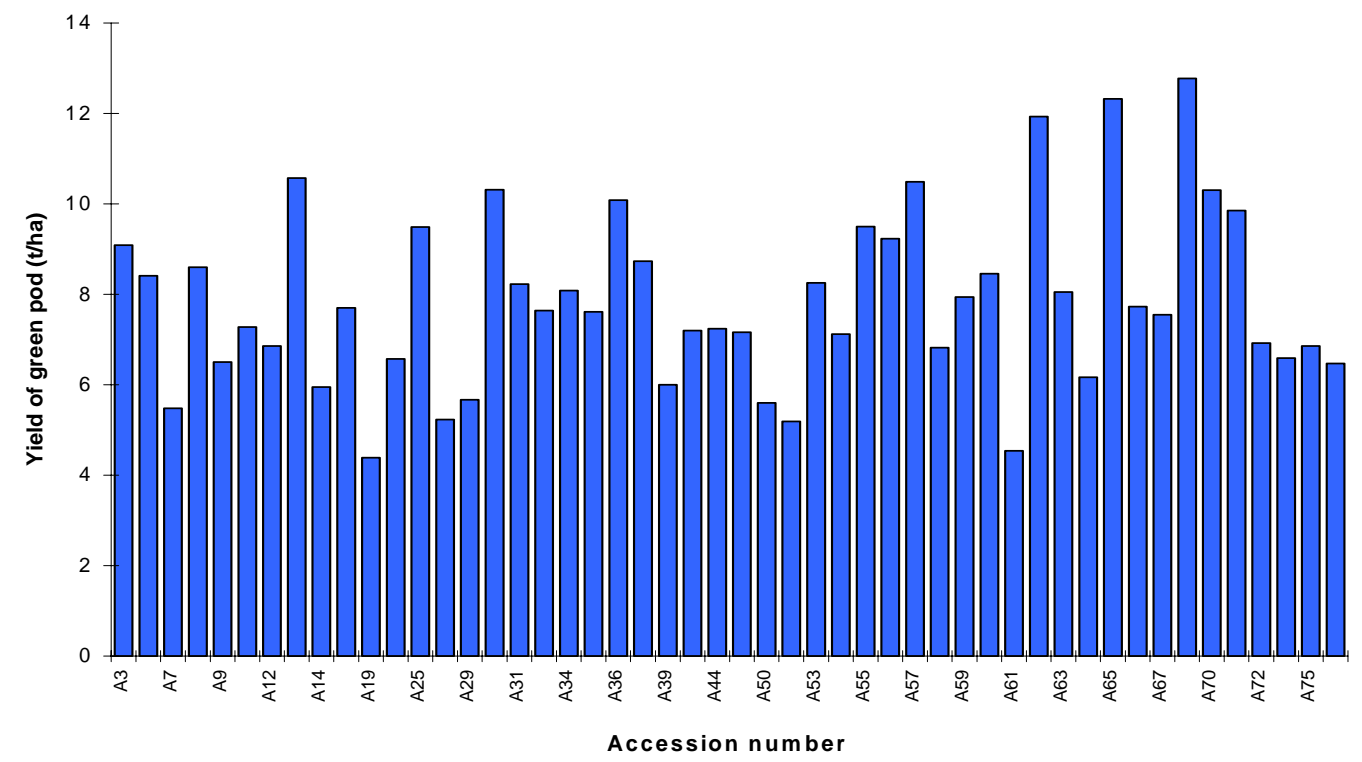

Fig. 2. Yield of green pod of 50 okra accessions. Vertical bar represents LSD at $5 \%$ level of probability 


\section{Correlation co-efficient}

Estimation of simple correlation co-efficient was made among five growth contributing characters like length of leaf, breadth of leaf, spread of plant, number of primary branches per plant and number of nodes per plant towards yield of the 50 okra accessions. The values of ' $r$ ' and the components correlated are presented in Table 5.

Table 5. Correlation co-efficient between yield and growth contributing characters in $\mathbf{5 0}$ okra accessions

\begin{tabular}{lccccc}
\hline \multicolumn{1}{c}{ Traits } & $\begin{array}{c}\text { Breadth } \\
\text { of leaf }\end{array}$ & $\begin{array}{c}\text { Spread of } \\
\text { plant }\end{array}$ & $\begin{array}{c}\text { No. of primary } \\
\text { branches/plant }\end{array}$ & $\begin{array}{c}\text { No. of nodes } \\
\text { per plant }\end{array}$ & $\begin{array}{c}\text { Yield of } \\
\text { green pod }\end{array}$ \\
\hline Length of leaf & -0.069 & -0.194 & -0.107 & 0.156 & 0.013 \\
Breadth of leaf & & $0.656^{* *}$ & $0.397^{*}$ & $-0.305^{*}$ & 0.023 \\
Spread of plant & & & $0.618^{\star}$ & $-0.293^{\star}$ & 0.000 \\
No. of primary branches per plant & & & & -0.122 & -0.095 \\
No. of nodes per plant & & & & & $0.359^{\star}$ \\
\hline
\end{tabular}

* indicate $5 \%$ level of significant (using mean values)

** indicate $1 \%$ level of significant (using mean values)

$\mathrm{df}=\mathrm{N}-2=50-2=48(5 \%=0.279,1 \%=0.361)$

\section{Length of leaf}

It was observed that length of leaf was negatively correlated with breadth of leaf, spread of plant and number of primary branches per plant. This indicate those trait will be less with the decrease of length of leaf. This character had positive association with number of nodes per plant and yield of green pod (Table 5).

\section{Breadth of leaf}

Breadth of leaf had highly significant and positive correlation with spread of plant $\left(r=0.656^{\star \star}\right)$ and number of primary branches per plant $\left(r=0.397^{\star}\right)$. This indicate those traits will be increased with the increase of breadth of leaf. On the other hand, breadth of leaf had significant and negative correlation $\left(r=-0.305^{\star}\right)$ with the number of nodes per plant. (Table 5).

\section{Spread of plant}

It was observed that spread of plant had highly significant positive correlation with number of primary branches per plant $\left(r=0.618^{\star}\right)$ suggesting that increase in spread of plant would lead simultaneous increase in primary branches per plant. On the other hand spread of plant had significant and negative correlation with number of nodes per plant $\left(r=-0.293^{\star}\right)$ which indicate that spread of plant will be increased with decrease in number of nodes per plant (Table 5). Paiva and Costa (1988) reported similar result in okra.

\section{Number of primary branches per plant}

It was observed that number of primary branches per plant was negatively correlated with the number of nodes per plant and yield of green pod (Table 5).

\section{Number of nodes per plant}

Correlation co-efficient revealed that number of nodes per plant had significant positive correlation with yield of green pod $\left(r=0.359^{\star}\right)$. This indicates that yield will be increased with the increase in number of nodes per plant (Table 5). This result was supported by Shukla (1990).

\section{Path analysis}

Simple correlation values were used to compute the path analysis. Direct and indirect effects of different growth contributing characters on yield of green pod have been shown in Table 6. 
Table 6. Path analysis showing direct and indirect effects on growth components towards yield in $\mathbf{5 0}$ okra accessions

\begin{tabular}{lcccccc}
\hline \multicolumn{1}{c}{ Traits } & $\begin{array}{c}\text { Length of } \\
\text { leaf }\end{array}$ & $\begin{array}{c}\text { Breadth of } \\
\text { leaf }\end{array}$ & $\begin{array}{c}\text { Spread of } \\
\text { plant }\end{array}$ & $\begin{array}{c}\text { No. of primary } \\
\text { branches/plant }\end{array}$ & $\begin{array}{c}\text { No. of nodes } \\
\text { per plant }\end{array}$ & $\begin{array}{c}\text { Yield of } \\
\text { green pod }\end{array}$ \\
\hline Length of leaf & $\underline{-0.00316}$ & -0.004 & -0.0045 & 0.083 & 0.0359 & 0.013 \\
Breadth of leaf & 0.0002 & $\underline{0.0592}$ & 0.0513 & -0.0309 & -0.070 & 0.023 \\
Spread of plant & 0.00061 & 0.0388 & $\underline{0.0234}$ & -0.048 & -0.0675 & 0.000 \\
No. primary branches per plant & 0.00033 & 0.0253 & 0.01447 & $\underline{0.0780}$ & -0.0281 & -0.095 \\
No. of nodes per plant & -0.00049 & 0.0180 & -0.00686 & 0.00951 & $\underline{0.230}$ & 0.359 \\
\hline
\end{tabular}

Residual effect: 0.728

Underlined figures indicate the direct effects.

\section{Length of leaf}

Path analysis reveled that direct effect of length of leaf on yield of green pod was very very low and negative $(-0.00316)$ whereas positive indirect effect was contributed via number of primary branches and number of nodes per plant.

\section{Breadth of leaf}

Breadth of leaf showed very low direct and positive effect (0.0592) on yield of green pod. This trait had also indirect positive effect on yield of green pod via length of leaf and spread of plant (Table 6).

\section{Spread of plant}

Spread of plant showed very low direct positive effect (0.0234) on yield of green pod, whereas indirect positive effect was contributed via length of leaf and breadth of leaf (Table 6). It was supported by Dash and Mishra (1995).

\section{Number of primary branches per plant}

Number of primary branches per plant showed very low positive direct effect $(0.078)$ on yield of green pod. This trait had also indirect effect on yield of green pod via diameter of green pod, weight of individual green pod, length of leaf, breadth of leaf and spread of plant (Table 6). Dash and Mishra (1995) reported similar result in respect of number of primary branches per plant.

\section{Number of nodes per plant}

Number of nodes per plant showed low direct effect (0.230) on yield of green pod whereas it had contributed indirect positive effect on yield of green pod via length of green pod, breadth of leaf and number of primary branches per plant (Table 6). Hazra and Basu (2000) observed similar result in respect of number of nodes per plant.

\section{CONCLUSION}

The result of the present experiment revealed that a wide variability exists among the collected okra accessions. These variability could be used for future breeding programme of okra in our country. The highest genotypic and phenotypic co-efficient of variation was observed in primary branches per plant. Also there was association of different growth contributing characters with the yield of okra. In respect of yield of green pod the accession number 69 had the highest followed by accessions 65, 62, 57 and 13 which were positively correlated with the plant height, number of nodes per plant, length of leaf, breadth of leaf and length of petiole. Therefore, accession number 69 is strongly recommended to be selected for okra cultivation followed by $65,62,57$ and 13 from the 50 accessions.

\section{LITERATURE CITED}

Anonymous. 1998. A leaflet on BARI Dherosh-I, a yellow vein mosaic disease resistant new variety of okra. USAID/BARC/AVRDC/BARI, Joydebpur, Dhaka, Bangladesh.

Anonymous. 1993. Research and development of vegetables crops. In "Workshop on Importance of Okra as Summer Vegetable". IPSA, Gazipur. pp. 1-7. 
BBS. 2004 . "Monthly Statistical Bulletin of Bangladesh (October)". Bangladesh Bureau of Statistics, Ministry of Planning, Government of People s' Republic of Bangladesh, Dhaka. 55 pp.

Dash, G, B. and Misra, P. K. 1995. Variation and character association of fruit yield and its component characters in okra (Abelmoschus esculentus L.). Current Agril Res 8(3/4), 123-127 [Cited in Hort Abstr 66(11), 1198, 1996].

Dewey, D. K. and Lu, K. H. 1959. A correlation and path co-efficient analysis of components of crested wheat grass and production. Agron J 51, 515-518.

Gomez, K. A. and Gomez, A. A. 1984. "Statistical Procedure for Agricultural Research". John Wiley and Sons. Inc, New York. pp. 67-215.

Gondane, S. U. and Bahatia, G. L. 1995. Response of okra genotypes to different environments. PKV Res J 19(2), 143-146.

Hammon, S. and Van Sloten, D. H. 1989. Characterization and evaluation of okra. In "The Use of Plant Genetic Resources". pp. 173-174.

Hazra, P. and Basu, D. 2000. Genetic variability, correlation and path analysis in okra. Ann Agril Res 21(3), 452-453.

Hussein, H. A., Farghali, M. A., El-zawahry, A. M. and Damarany, A. M. 1994. Growth, yield and nematode reaction in some okra accessions. Assiut J Agril Sci 25(3), 113-129 [Cited in Hort. Abstr 66(1), 58, 1996].

Kochhar, S. L. 1986. "Tropical Crops" The Macmillan Press Ltd., New Delhi. pp. 263-264.

Kuwada, H. 1964. Studies on varietal characters and their classification in okra (Abelmoschus esculentus). Tech Bull Fac Agril Kagawa 15, 79-88 [Cited in Hort Abstr 35(1), 122, 1965].

Lotilo, S. 1989. Assessing the viability of seeds of okra (Abelmoschus esculentus $L$ ) by biochemical assay. Cilture Protette 18(11), 93-94 [Cited in Hort Abstr 60(6), 500, 1990].

Martin, F. W. and Rhodes, A. M. 1983. Seed characteristics of okra and related Abelmoschus species. Qualitas Plantarum 33(1), 41-49 [Cited from Hort Abstr 54(1), 19, 1984].

Paiva, W. O. and Costa, C. P. 1988. Genetic parameters in okra. Pesquisa Agropecuaria Brasileira, 33(5), 705-712 [Cited from Hort Abstr 21(1), 77, 1989].

Rashid, M. M. 1999. "Sabji Biggan". Rashid Publishing House, Dhaka, 476 p.

Shukla, A. K. 1990. Correlation and path co-efficient analysis in okra. Prog Hort 22(1-4), 156-159.

Singh, A. K., Singh, K. P. and Singh, V. P. 1998. Genetic analysis of induced mutation of okra, Abelmoschus esculentus L. Veg Sci 25(2), 174-177.

Singh, K. B. and Singh, H. N. 1977. Path co-efficient analysis for yield in okra. Indian J Agric Sci 49, 244-246.

Singh, R. K. and Chaudhury, B. D. 1985. Biometrical methods of quantitative genetic analysis. Harayana J Hort Sci 12(2), 151-156.

Sood, S., Arya, P. S. and Singh, Y. 1995. Genetic variability and correlation studies in okra Abelmoschus esculentus L. Adv Hort Forest 4(4), 109-118. 